P-ISSN: 2615-1723

E-ISSN: 2615-1766

April 2018
Jurnal Riset Pendidikan Dasar

1 ( 1), ( 2018) 40-48

Submitted: Februari, Accepted: Maret, Published: April

\title{
PENGARUH PENGGUNAAN MEDIA GAMBAR TERHADAP HASIL BELAJAR BAHASA INDONESIA PADA SISWA KELAS IV SEKOLAH DASAR
}

\author{
Ahmad Ali Akbar", Tarman \\ Pendidikan Dasar Pascasarjana Universitas Muhammadiyah Makassar, Indonesia \\ *Korespondensi. E-mail: aa9540048@gmail.com
}

\begin{abstract}
Abstrak
Penggunaan media gambar sangat membantu untuk meningkatkan hasil belajar siswa, Karena melibatkan seluruh potensi yang dimiliki oleh siswa. Tujuan dari penelitian ini untuk mengatahui pengaruh penggunaan Media gambar terhadap hasil belajar Bahasa Indonesia, Karna hasil belajar siswa kelas IV SD Negeri Sungguminasa III Kecamatan Somba Opu Kabupaten Gowa tergolong rendah dengan nilai 6,83. Jenis penelitian yang digunakan adalah pre eksperimental dengan jenis one group pre test-post test design. Teknik yang digunakan untuk mengumpulkan data adalah teknik tes. Data yang dikumpul akan dianalisis dengan menggunakan teknik statistik deskriptif jenis uji t-tes. Hasil penelitian ini menunjukkan bahwa penggunaan media gambar pada proses pembelajaran pada hasil belajar berpengaruh. Hal ini tampak pada tingkat kemampuan siswa sebelum menggunakan metode pembelajaran yaitu hanya mencapai 6,83 , selanjutnya setelah menggunakan media gambar pada proses pembelajaran mencapai nilai rata-rata yang diperoleh sebesar 16,35. Hal ini berarti bahwa tingkat kemampuan siswa meningkat. Pengaruh media gambar dalam proses pembelajaran diketahui pula berdasarkan hasil perhitungaan uji $t$. Hasil penelitian diperoleh, $t_{\text {Hitung }}=$ 16,41 dan $t_{\text {Tabel }}=3,792$ maka $t_{\text {Hitung }} \geq t_{\text {Tabel }}$ atau 16,41 $\geq 3,792$. Sehingga dapat disimpulkan bahwa $H_{o}$ di tolak dan $\mathrm{H}_{\mathrm{a}}$ diterima. Ini berarti bahwa penggunaan media gambar dapat memberi pengaruh dalam meningkatkan kemampuan siswa pada pelajaran Bahasa Indonesia.
\end{abstract}

Kata Kunci: Metode Pembelajaran, Diskusi Kelompok, Berbicara

\section{INFLUENCE OF USE OF MEDIA IMAGES ON INDONESIAN LEARNING RESULT IN STUDENTS OF SCHOOL IV BASIC SCHOOL}

\begin{abstract}
The use of image media is very helpful to improve student learning outcomes, because it involves all the potential possessed by students. The purpose of this study to mengatahui effect of the use of media images of learning outcomes Indonesian, Karna student learning outcomes fourth grade SD Negeri Sungguminasa III Somba Opu District Gowa is low with a value of 6.83. The type of research used is pre experimental with type one group pre test-post test design. The technique used to collect data is a test technique. The collected data will be analyzed using descriptive statistical technique of test t-test type. The results of this study indicate that the use of image media on the learning process on learning results have an effect. This is seen in the level of students' ability before using the learning method that is only reached 6.83, then after using the media images on the learning process to reach the average value obtained for 16.35 . This means that the level of student ability increases. The influence of image media in the learning process is also known based on the results of $t$ test calculation. The results obtained, $t=16.41$ and tTable $=3.792$ then $t$ Count $\geq$ tTable or $16.41 \geq 3.792$. So it can be concluded that Ho is rejected and Ha accepted. This means that the use of image media can have an effect on improving students' skills in Indonesian language.
\end{abstract}

Keywords: Learning methods, Group discussions, Speaking

Copyright C2018, JRPD, ISSN 2615 - 1723 (Print), ISSN 2615 - 1766 (Online) 


\section{PENDAHULUAN}

Guru merupakan komponen yang sangat penting dalam mengoptimalkan hasil proses belajar mengajar (Fullan, 2007; Sulfasyah, Haig \& Barratt-Pugh, 2015). Guru berfungsi sebagai komunikator yang menyampaikan materi pelajaran kepada siswa. Dan dalam menyampaikan materi, guru memerlukan saluran (media pembelajaran) agar materi dapat diterima oleh siswa dengan baik.

Secara umum semua anak berkembang melalui urutan yang sama, meskipun jenis dan tingkat pengalaman berbeda satu sama lainnya. Perkembangan mental anak terjadi secara bertahap dari tahap yang satu ketahap yang lebih tinggi. semua perubahan yang terjadi pada setiap tahap tersebut merupakan kondisi yang diperlukan untuk mengubah atau meningkatkan tahap perkembangan moral berikutnya. Aunurrahman (2013: 58)

Sesuatu hal yang juga tidak boleh dilupakan oleh guru sekolah dasar ini adalah guru hendaknya memahami karakteristik siswa yang akan diajarkan. Karena anak yang berada di sekolah dasar masih tergolong anak usia dini, terutama di kelas awal adalah anak yang berada pada rentangan usia dini. Masa usia dini ini merupakan masa yang pendek tetapi merupakan masa yang sangat penting bagi seseorang. oleh karena itu, pada masa ini seluru potensi yang dimiliki anak perlu didorong secara optimal. Siswa sekolah dasar merupakan masa transisi dari sekolah taman kanak-kanak kesekolah dasar. Susanto Ahmad (2014: 70).

Perkembangan baru yang setiap saat muncul terhadap pandangan komunikasi pembelajaran, membawa konsekuensi kepada guru untuk senantiasa meningkatkan kemampuan dan kompetensi mengajar termasuk dalam menggunakan media gambar pada saat menyajikan materi di depan kelas. Guru sebagai fasilitator dalam komunikasi pembelajaran harus menyadari bahwa salah satu faktor yang menyebabkan rendahnya hasil belajar siswa adalah kurang pedulinya guru menggunakan media pembelajaran setiap menyajikan materi.

Penggunaan media pembelajaran cukup memberikan konstribusi positif yang mempengaruhi hasil belajar siswa jika guru menggunakannya dengan cara benar, disamping menggunakan buku cetak sebagai sumber belajar, juga menampilkan salah satu media tiga dimensi yang dapat dilihat langsung oleh siswa seperti model benda dan dalam memberikan penjelasan menggunakan media pembesar suara dan media lain yang dianggap penting.

Jika seandainya keseluruhan guru SD menggunakan media pembelajaran secara komprehensif seperti yang disebutkan di atas, maka dapat dipastikan bahwa siswa akan mencapai hasil belajar yang tinggi dan tidak terjadi dengan keadaan sekarang, bahwa ada beberapa SD di Kabupaten Gowa, lebih khusus di kelas IV SD Negeri Sungguminasa III rendah hasil belajarnya, utamanya pada mata pelajaran Bahasa Indonesia.

Pengaruh penggunaan media pembelajaran terhadap hasil belajar diakui oleh para ahli lewat penelitian. Dale dalam Basuki (1992: 75) menyatakan pengalaman belajar seseorang diperoleh melalui indra mata sebesar $75 \%$, indra dengar $13 \%$, dan selebihnya melalui indra lain.

Raharjo dalam Basuki (1992:3) menjelaskan bahwa penelitian yang ditujukan pada kegiatan belajar mengajar akan lebih efektif dan mudah bila dibantu dengan sarana visual. Dikatakan bahwa $11 \%$ dari apa yang dipelajari lewat indra pendengar, $85 \%$ lewat indra penglihatan. Disamping itu, juga mengemukakan bahwa hanya yang dapat diingat $20 \%$ dari apa yang didengar dan $50 \%$ dari apa yang didengar dan dilihat.

Dari kedua hasil penelitian di atas, memberikan gambaran bahwa penggunaan media pembelajaran sangat membantu untuk meningkatkan hasil belajar siswa. Karena dengan menggunakan media pembelajaran

Copyright (C2018, JRPD, ISSN 2615 - 1723 (Print), ISSN 2615 - 1766 (Online) 
berarti melibatkan seluruh potensi yang dimiliki oleh siswa, dan ternyata berdasarkan kedua pendapat di atas bahwa indra penglihatan yang menempati posisi tertinggi dalam menerima sebuah pelajaran.

Hal ini terwujud bila terjadi kesesuaian penggunaan media dengan tujuan pembelajaran. Semua materi pelajaran memiliki tingkat kesukaran yang bervariasi. Pada satu sisi ada bahan pelajaran yang memerlukan alat bantu dan disisi lain tidak perlu menggunakan alat bantu berupa media.

bahwa penggunaan media pembelajaran sangat membantu untuk meningkatkan hasil belajar siswa. Karena dengan menggunakan media pembelajaran berarti melibatkan seluruh potensi yang dimiliki oleh siswa, bahwa indra penglihatan yang menempati posisi tertinggi dalam menerima sebuah pelajaran.

Berlandastumpu pada uraian di atas, Hasil pembelajaran bahasa indonesia di Negeri Sungguminasa III, menarik diteliti dengan alasan: (1) rendah hasil belajarnya, utamanya pada mata pelajaran Bahasa Indonesia.; (2)penggunaan media ajar dalam proses belajar mengajar masih jarang digunakan khususnya dalam mata pelajaran bahasa Indonesia; dan (3) SD Negeri Sungguminasa III, belum pernah dilakukan penelitian yang berkaitan dengan pengaruh penggunaan media gambar, Dalam hal ini, menyangkut bagaimana peran media dalam pembelajaran, bagaimana hasil pembelajaran jika menggunakan media gambar, adakah pengarug media gambar dalam pembelajaran khususnya dalam mata pelajaran bahasa indonesia

Perkembangan ilmu pengetahuan dan teknologi semakin mendorong upaya-upaya pembaharuan dalam pemanfaatan hasil-hasil teknologi dalam proses belajar. Hal tersebut menuntut agar guru/pengajar mampu menggunakan alat-alat yang disediakan oleh sekolah, dan tidak tertutup kemungkinan bahwa alat tersebut sesuai perkembangan dan tuntutan zaman. Hamalik (Kustandi dkk,
2013:6) Guru sekurang-kurangnya dapat menggunaka media yang murah dan efesien yang meskipun sederhana, tetapi merupakan keharusan dalam upaya mencapai tujuan pembelajaran yang diharapkan. Untuk itu, guru/pengajar harus memiliki pengetahuan dan pemahaman yang cukup tentang media pembelajaran

Berangkat dari harapan yang dituangkan dalam kurikulum, tujuan pendidikan nasional dengan kenyataan yang ada di lapangan, yang mana pada kenyataannya tetap hasil belajarnya rendah, maka muncul berbagai masalah. Dan dengan kondisi seperti ini penulis mengangkat judul "Pengaruh Penggunaan Media Gambar Terhadap Hasil Belajar Bahasa Indonesia Siswa Kelas IV SD Negeri Sungguminasa III Kecamatan Somba Opu Kabupaten Gowa".

Media yang dimaksud dalam penelitian ini adalah media yang digunakan dalam komunikasi pembelajaran di kelas IV SD Negeri Sungguminasa III Kecamatan Somba Opu yaitu berupa gambar. Yang akan diterapkan dalam proses belajar mengajar pada bidang studi Bahasa Indonesia.

Hasil belajar yang dimaksud dalam penelitian ini adalah nilai pada mata pelajaran Bahasa Indonesia sesuai yang diharapkan dengan cara pemberian evaluasi, pada kelas IV SD Negeri Sungguminasa III.

Berdasarkan latar belakang diatas, masalah penelitian ini dapat dirumuskan sebagai berikut: Apakah ada pengaruh penggunaan Media gambar terhadap hasil belajar Bahasa Indonesia siswa kelas IV SD Negeri Sungguminasa III.

Dari rumusan masalah yang dikemukakan diatas, maka tujuan penelitian ini yaitu untuk mengatahui pengaruh penggunaan Media gambar terhadap hasil belajar Bahasa Indonesia siswa kelas IV SD Negeri Sungguminasa III.

Pada penelitian ini yang akan dilakukan oleh peneliti adalah melakukan proses pembelajaran menggunakan KTSP 2006 dengan mengajarkan pembelajaran 
bahasa Indonesia menggunakan dua siklus diaman siklis pertama tidak menggunakan media gambar, kemudian disiklus kedua peneliti menggunakan media gambar dalam proses belajar mengar. Kemudian membandingkan bagaiaman hasil belajar bahasa indonesia sebelum dan sesuda menggunakan media gambar pada proses belajar Bahasa Indonesia siswa kelas IV SD Negeri Sungguminasa III Kecamatan Somba Opu Kabupaten Gowa.

\section{METODE PENENLITIAN}

Jenis penelitian ini adalah penelitian eksperimen. Penelitian eksperimen merupakkan penelitian sistematis, logis dan teliti untuk melakukan kontrol terhadap kondisi, yang bertujuan mengungkapkan pengaruh penggunaan media gambar terhadap hasil belajar Bahasa Indonesia siswa kelas IV SD Negeri Sungguminasa III Kecamatan Somba Opu Kabupaten Gowa. Desain eksperimen yang digunakan adalah one group pre test post-test design. Dengan pola sebagai berikut:

$\mathrm{O}_{1} \times \mathrm{O}_{2}$

Keterangan :

$\mathrm{O}_{1} \quad$ : Pengukuran pertama (awal) sebelum subjek diberi perlakuan (pretest)

$\mathrm{X}$ :Treatmen atau perlakuan (penggunaan media gambar))

$\mathrm{O}_{2} \quad$ : Pengukuran kedua setelah diberi perlakuan (post-test)

Prosedur pelaksanaan penelitian yaitu dimulai dari tahap perencanaan, pelaksanaan, evaluasi dan analisis. Adapun prosedur pelaksanaannya, yaitu:

1. Tahap Perencanaan

Tahap perencanaan ini dilakukan dengan menentukan subjek eksperimen terhadap siswa kelas IV SD Negeri Sungguminasa III Kecamatan Somba Opu Kabupaten Gowa, sebanyak 13 orang. Kegiatan ini meliputi penetapan berupa bahan ajar yang akan diberikan selama penelitian berjalan, tujuan yang ingin dicapai, sasaran kegiatan, waktu, dan tempat pelaksanaan.

2. Tahap Pelaksanaan

Adapun tahap pelaksanaan yang terdiri dari:

a) Pelaksanaan pre-test terhadap subjek eksperimen.

b) Pelaksanaan treatmen atau perlakuan yaitu penggunaan media gambar pada saat pembelajaran berlangsung

c) Pelaksanaan post-test terhadap subjek eksperimen.

3. Tahap Evaluasi

Pada tahap evaluasi ini peneliti memberikan umpan balik dengan memberikan beberapa pertanyaan kepada murid untuk dijawab. Hal ini dilakukan untuk mengetahui pengaruh penggunaan media gambar.

4. Tahap Analisis

Tahap ini dilakukan untuk kebutuhan analisis data, dicari selisih skor antara pre test dan post-test.

5. Temuan, nilai selisih tersebut yang dibandingkan dengan t-tes.

Pada tulisan ini telah ditetapkan populasinya yaitu siswa SD Negeri Sungguminasa III Jumlah sampel kelas IV sebanyak 23 siswa yang terdiri dari 12 orang laki-laki dan 11 orang perempuan Tahun Pelajaran 2015-2016.

Dengan demikian sampel dalam penelitian ini terfokus pada satu kelas saja yaitu hanya kelas IV dengan jumlah siswa 23 orang, dimana kelas IV ini dijadikan sebagai kelas control dan eksperimen.

Instrumen yang digunakan dalam penelitian ini adalah tes penilaian hasil belajar bahasa Indonesia. Tes ini dimaksud untuk mengukur hasil belajar bahasa Indonesia siswa kelas IV SD Negeri Sungguminasa III Kecamatan Somba Opu Kabupaten Gowa yang diperoleh sebelum dan sesudah diberikan perlakuan dalam jangka waktu tertentu.

Bentuk tes yang digunakan adalah soal tes essay, yang dibuat oleh penulis berdasarkan materi kelas IV. Item-item tes dibuat pada

Copyright (C2018, JRPD, ISSN 2615 - 1723 (Print), ISSN 2615 - 1766 (Online) 
materi yang diberikan selama penelitian berlangsung.

Teknik pengumpulan data pada penelitian ini menggunakan observasi dan instrument tes. Metode observasi digunakan untuk mengamati sejauh mana keefektifan penggunaan media gambar dalam pembelajaran bahasa Indonesia siswa kelas IV di SD Negeri Sungguminasa III.

Dalam usaha mengumpulkan data sebagai bahan masukan untuk diolah, maka dipilih teknik sebagai berikut:

\section{Observasi}

Teknik observasi, digunakan oleh penulis untuk mengamati secara langsung siswa dalam kelas, terutama siswa yang diambil sebagai sampel penelitian. Dalam hal ini siswa memperlihatkan potensi-potensi yang dimiliki, yang mendapat rangsangan dari guru secara optimal.

2. Dokumentasi

Dokumentasi adalah informasi yang disimpan baik yang bersifat surat-surat, laporan, foto, nilai siswa, dan sebagainya sebagai bahan dokumen. Teknik ini digunakan untuk melengkapi data-data dan menjadi bukti teori yang relevan mengenai kegiatan guru, siswa dan peneliti pada saat proses penelitian berlangsung.

3. Tes

Bentuk tes yang digunakan adalah tes tertulis yaitu siswa ditugasi menjawab soal yang diberikan oleh guru.

Analisis data penelitian dimaksudkan untuk menganalisis data hasil tes penelitian berkaitan dengan pengaruh penggunaan media gambar, teknik analisis data yang digunakan adalah analisis deskriptif dan analisis t-tes.

Adapun teknik analisis data dalam penelitian ini, yaitu:

\section{Analisis Statistik Deskriptif}

Analisis statistik deskriptif dimaksudkan untuk menggambarkan kurangnya hasil belajar bahasa Indonesia siswa kelas IV SD Negeri Sungguminasa III Kecamatan Somba Opu
Kabupaten Gowa, sebelum (pre-test) dan sesudah (post-test) perlakuan berupa penggunaan media gambar.

$$
\begin{aligned}
& \text { Adapun rumus persentase, yaitu : } \\
& \mathrm{P}=\frac{f}{\mathrm{~N}} \times 100
\end{aligned}
$$

Keterangan:

$$
\begin{array}{ll}
\mathrm{P} & : \text { Persentase } \\
f & : \text { Frekuensi } \\
\mathrm{N} & \text { : Jumlah subjek (sampel) }
\end{array}
$$

Guna memperoleh gambaran umum tentang kurangnya hasil belajar bahasa Indonesia siswa kelas IV SD Negeri Sungguminasa III Kecamatan Somba Opu Kabupaten Gowa, sebelum dan sesudah diberikan penggunaan media gambar, maka untuk keperluan tersebut, dilakukan perhitungan rata-rata skor peubah dengan rumus.

Adapun rumus tersebut, yaitu:

$$
M e=\frac{\sum X i}{N}
$$

Keterangan:

$$
\begin{array}{ll}
\text { Me } & \text { : Mean (rata-rata) } \\
\mathrm{Xi} & \text { : Jumlah nilai } \\
\mathrm{N} & \text { : Banyaknya subjek (sampel) }
\end{array}
$$

Setelah rata-rata skor telah didapat, maka peneliti mengklasifikasikan hasil tersebut dengan nilai sebagai berikut :

Tabel. 1 Kategorisasi tingkat hasil belajar

\begin{tabular}{cc}
\hline Interval & Kategori \\
\hline $1-5$ & Sangat Rendah \\
$6-10$ & Rendah \\
$11-15$ & Sedang \\
$16-20$ & Tinggi \\
\hline
\end{tabular}

2. Uji T-Test

T-tes dimaksudkan untuk menguji hipotesis penelitian mengenai ada tidaknya pengaruh penggunaan media gambar terhadap hasil belajar sebelum (pre-test) dan sesudah (post-test) diberikan latihan pada murid kelas IV

Copyright C2018, JRPD, ISSN 2615 - 1723 (Print), ISSN 2615 - 1766 (Online) 
SD Negeri Sungguminasa III. Tingkat signifikan yang digunakan 0,05 dengan kriteria adalah "tolak $\mathrm{H}_{0}$ jika $\mathrm{t}$ hitung $\geq \mathrm{t}$ tabel dan diterima $\mathrm{H}_{0}$ jika $\mathrm{t}$ hitung $\leq \mathrm{t}$ tabel.

$$
t=\frac{M d}{\sqrt{\frac{\sum X^{2} d}{N(N-1)}}}
$$

Keterangan:

Md :Meaan dari perbedaan pretes dan postes $\mathrm{Xd} \quad$ : Deviasi masing-masing subjek (d-Md) $\sum X^{2} d$ : Jumlah kuadrat deviasi

$\mathrm{N} \quad$ : Subjek pada sampel

$\mathrm{db} \quad$ : Ditentukan dengan N-1

\section{HASIL DAN PEMBAHASAN}

Berdasarkan hasil data penelitian yang telah dilakukan oleh peneliti dapat diuraikan dan dideskripsikan secara rinci hasil penelitian tentang pengaruh penggunaan media gambar terhadap hasil belajar siswa kelas IV SD Negeri Sungguminasa III Kecamatan Somba Opu Kabupaten Gowa. Untuk mengetahui pengaruh penggunaan media gambar terhadap hasil belajar siswa kelas IV SD Negeri Sungguminasa III Kecamatan Somba Opu Kabupaten Gowa, terlebih dahulu perlu dianalisis tentang (1) kemampuan Bahasa Indonesia siswa kelas IV SD Negeri Sungguminasa III sebelum menggunakan media gambar dalam proses pembelajaran (pre test) dan (2) kemampuan hasil belajar Bahasa Indonesia siswa kelas IV SD Negeri Sungguminasa III setelah menggunakan media gambar dalam proses pembelajaran (post test).

Hasil penelitian tersebut dianalisis dengan menggunakan analisis statistik deskriptif untuk menggambarkan tingkat kemampuan hasil sebelajar selum (pre test) dan sesudah (post test) diberi perlakuan, dan analisis statistik inferensial untuk menguji hipotesis penelitian tentang adanya perbedaan tingkat kemampuan hasil belajar sebelum dan sesudah diberi perlakuan berupa penggunaan media gambar dalam proses pembelajaran.

Analisis statistik deskriptif dimaksudkan untuk memperoleh gambaran mengenai tingkat kemampuan hasil belajar sebelum (pre test) dan sesudah (post test) diberi perlakuan berupa penggunaan media gambar dalam proses pembelajaran terhadap siswa kelas IV SD Negeri Sungguminasa III Kecamatan Somba Opu Kabupaten Gowa, maka berikut ini akan disajikan dalam bentuk tabel distribusi frekuensi yang diklasifikasikan dalam 4 (empat) kategori, yaitu tingkat kemampuan siswa dalam hasil belajar tinggi, sedang, dan rendah.

Kemampuan Bahasa Indonesia siswa kelas IV SD Negeri Sungguminasa III Kecamatan Somba Opu Kabupaten Gowa, sebelum penggunaan media gambar dalam proses pembelajaran bahasa Indonesia., tingkat kemampuan hasil belajar yaitu hanya 1 siswa $(4,35 \%)$ yang berada pada kategori tinggi, kemudian kategori sedang sebanyak 3 siswa $(13,04 \%)$, kemudian pada kategori rendah sebanyak 7 siswa $(30,43 \%)$, sedangkan pada kategori sangat rendah sebanyak 12 siswa $(52,17 \%)$. Selanjutnya sesuai dengan nilai ratarata yang diperoleh sebesar 6,83 dimana nilai rata-rata tersebut pada interval 6-10 yang berarti rendah. Hal ini berarti bahwa tingkat kemampuan hasil belajar Bahasa Indonesia siswa kelas IV SD Negeri Sungguminasa III Kecamatan Somba Opu Kabupaten Gowa berada pada kategori rendah.

Setelah diberi perlakuan dengan menggunakan media gambar dalam proses pembelajaran sebanyak 2 kali latihan, tingkat kemampuan hasil belajar siswa kelas IV SD Negeri Sungguminasa III Kecamatan Somba Opu Kabupaten Gowa mengalami peningkatan. Hal ini dapat dilihat dari tingkat hasil belajar siswa yang berada dalam kategori tinggi sebanyak 16 siswa $(69,57 \%)$, kategori sedang sebanyak 5 siswa $(21,74 \%)$, kategori rendah sebanyak $2(8,7 \%)$ siswa dan tidak ada siswa yang berada pada kategori sangat rendah. Selanjutnya sesuai dengan nilai ratarata yang diperoleh sebesar 16,35 dimana nilai rata-rata tersebut berada pada interval 16-20 yang berarti tinggi. Hal ini menunjukkan bahwa tingkat hasil belajar siswa setelah diberikan pembelajaran dengan menggunakan media gambar berada pada kategori tinggi.

Dari hasil observasi selama kegiatan latihan media gambar dalam proses pembelajaran yang dilaksanakan dalam dua tahap, pertemuan pertama, tidak ada yang berada pada kriteria tinggi, pertemuan kedua 10 siswa. Pada kriteria sedang, pertemuan

Copyright (C2018, JRPD, ISSN 2615 - 1723 (Print), ISSN 2615 - 1766 (Online) 
pertama 7 siswa, pertemuan kedua 13 siswa. Pada kriteria rendah, pertemuan pertama 15 siswa dan pada pertemuan kedua tidak ada siswa yang berada pada kriteria tersebut. Selanjutnya 1 siswa yang berada pada kriteria sangat rendah pada pertemuan pertama dan pada pertemuan kedua tidak ada siswa yang berada pada kriteria tersebut. kehadiran murid $100 \%$ baik pada pertemuan pertama dan kedua. $52,17 \%$ perhatian murid terhadap penjelasan yang diberikan pada pertemuan pertama dan pertemuan kedua $73,91 \%$. $30,43 \%$ yang mengajukan pertanyaan pada pertemuan pertama dan kedua $73,91 \%$. $52,17 \%$ yang melaksanakan setiap intruksi yang diberikan, dan pada pertemuan kedua $82,61 \%$. 47,83\% yang mengerjakan soal latihan dan pertemuan kedua $93,3 \%$. 52,17\% yang menjawab pertanyaan pada pertemuan pertama dan pertemuan kedua 95,65\%. $60,87 \%$ yang berpartisipasi aktif selama kegiatan berlangsung dan pada pertemuan kedua $78,26 \%$. 56,52\% yang mengikuti kegiatan secara sukarela pada pertemuan pertama dan pertemuan kedua $73,91 \%$. Selanjutnya $34,78 \%$ yang mampu menilai kegiatan yang dilakukan pada pertemuan pertama, pertemuan kedua $73,91 \%$.

Hipotesis penelitian ini adalah "penggunaan media gambar terhadap hasil belajar Bahasa Indonesia siswa kelas IV SD Negeri Sungguminasa III kecamatan Somba Opu Kabupaten Gowa". Untuk pengujian hipotesis di atas, terlebih dahulu disajikan data tingkat hasil belajar bahasa indonesia, baik pre test dan post test. Hasil uji akan diuraikan di bawah ini. Rumus yang digunakan adalah:

$$
t=\frac{M d}{\sqrt{\frac{\sum X^{2} d}{N(N-1)}}}
$$

\section{Keterangan:}

Md :Meaan dari perbedaan pretes dan postes

Xd : Deviasi masing-masing subjek (d-Md)

$\sum X^{2} d$ : Jumlah kuadrat deviasi

$\mathrm{N} \quad$ : Subjek pada sampel

$\mathrm{db} \quad$ : Ditentukan dengan N-1

jumlah siswa kelas IV SD Negeri Sungguminasa III sebanyak 23 orang. Jumlah nilai pre test yang diperoleh adalah 157 dan jumlah nilai post test yang diperoleh adalah 376. Rentang antara nilai pre test dan post test adalah 219.

$$
M d=\frac{\sum d}{N}=\frac{219}{23}=9,52
$$

Menentukan harga $\mathrm{T}_{\text {Hitung: }}$ :

$$
\begin{gathered}
t=\frac{M d}{\sqrt{\frac{\sum X^{2} d}{N(N-1)}}}=\frac{9,52}{\sqrt{\frac{171,73}{23 \times 22}}}=16,41 \\
t=16,41
\end{gathered}
$$

Menentukan harga $t_{\text {Tabel }}$ :

Untuk mencari $t$ Tabel peneliti menggunakan tabel distribusi $\mathrm{t}$ dengan taraf signifikan $\alpha=$ 0,05 dan d.b. $=\mathrm{N}-1=23-1=22$.

Berdasarkan tabel $\mathrm{t}$, maka diperoleh $\mathrm{t}_{0,05}$ $=3,792$. Setelah diperoleh $t_{\text {Hitung }}=16,41$ dan $\mathrm{t}_{\text {Tabel }}=3,792$ maka $\mathrm{t}$ Hitung $\geq \mathrm{t}$ Tabel atau 16,41 $\geq$ 3,792 . Sehingga dapat disimpulkan bahwa $\mathrm{H}_{\mathrm{o}}$ di tolak dan $\mathrm{H}_{\mathrm{a}}$ diterima. Ini berarti bahwa ada pengaruh positif yang signifikan terhadap hasil belajar bahasa Indonesia siswa kelas IV SD Negeri Sungguminasa III.

Dalam pengujian statistik, hipotesis ini dinyatakan sebagai berikut:

$$
\begin{gathered}
H_{0}: t_{\text {hitung }} \leq t_{\text {tabel }} \text { lawan } H_{1} \\
: t_{\text {hitung }} \geq t_{\text {tabel }}
\end{gathered}
$$

Penelitian ini dilakukan untuk mengetahui pengaruh pengaruh penggunaan media gambar terhadap hasil belajar bahasa Indonesia kelas IV SD Negeri Sungguminasa III Kecamatan Somba Opu Kabupaten Gowa.

Dalam proses penelitian ini siswa diberikan perlakuan berupa penggunaan media gambar dalam proses pembelajaran yang terdiri dari 2 kali pertemuan dengan tmateri yang sama dan disetiap selesai diberikan latihan latihan, peneliti berdiskusi dengan siswa dengan merefleksikan pelatihan penggunaan media gambar, sehingga diharapkan setelah melakukan kegiatan ini siswa dapat lebih tekun belajar sesuai model dan metode guru yang diberikan. 
Berdasarkan hasil analisis observasi terhadap kegiatan belajar siswa saat pelaksanaan penggunaan media gambar terhadap persentase individual diperoleh data bahwa, pada hakikatnya terjadi peningkatan partisipasi siswa selama pelatihan pembelajaran dengan menggunakan media gambar dimana pada pertemuan pertama, tidak ada yang berada pada kriteria tinggi, pertemuan kedua 10 siswa. Pada kriteria sedang, pertemuan pertama 7 siswa, pertemuan kedua 13 siswa. Pada kriteria rendah, pertemuan pertama 15 siswa dan pada pertemuan kedua tidak ada murid yang berada pada kriteria tersebut. Selanjutnya 1 siswa yang berada pada kriteria sangat rendah pada pertemuan pertama dan pada pertemuan kedua tidak ada siswa yang berada pada kriteria tersebut.

Tingkat persentase partisipasi kegiatan belajar siswa dengan menerapkan penggunaan media gambar berdasarkan hasil analisis persentase kelompok diperoleh data bahwa kehadiran murid $100 \%$ baik pada pertemuan pertama dan kedua. 52,17\% perhatian murid terhadap penjelasan yang diberikan pada pertemuan pertama dan pertemuan kedua $73,91 \%$. 30,43\% yang mengajukan pertanyaan pada pertemuan pertama dan kedua $73,91 \%$. $52,17 \%$ yang melaksanakan setiap intruksi yang diberikan, dan pada pertemuan kedua $82,61 \% .47,83 \%$ yang mengerjakan soal latihan dan pertemuan kedua 93,3\%. 52,17\% yang menjawab pertanyaan pada pertemuan pertama dan pertemuan kedua 95,65\%. $60,87 \%$ yang berpartisipasi aktif selama kegiatan berlangsung dan pada pertemuan kedua $78,26 \%$. 56,52\% yang mengikuti kegiatan secara sukarela pada pertemuan pertama dan pertemuan kedua $73,91 \%$, selanjutnya $34,78 \%$ yang mampu menilai kegiatan yang dilakukan pada pertemuan pertama, pertemuan kedua $73,91 \%$.

Dengan demikian hal ini memberikan indikasi bahwa terjadi peningkatan pada setiap kali pertemuan disebabkan karena setiap siswa serius dan bersungguh-sungguh mengikuti kegiatan, setiap individu melakukan kegiatan dengan baik dan peneliti melaksanakan kegiatan sesuai dengan rencana yang telah ditetapkan sebelumnya.

Berdasarkan hasil analisis statistik deskriptif, diperoleh data bahwa pada hakikatnya terdapat perubahan tingkat hasil belajar, hal ini dapat dilihat dari tingkat hasil belajar siswa dominan berada dalam kategori tinggi sebanyak 16 siswa $(69,57 \%)$, kategori sedang sebanyak 5 siswa $(21,74 \%)$, kategori rendah sebanyak $2(8,7 \%)$ siswa dan tidak ada siswa yang berada pada kategori sangat rendah. Selanjutnya sesuai dengan nilai ratarata skor yang diperoleh sebesar 16.35 dimana nilai rata-rata tersebut berada pada interval 1620 yang berarti tinggi. Hal ini menunjukkan bahwa tingkat hasil belajar siswa kelas IV SD Negeri Sungguminasa III berada pada kategori tinggi. Dengan demikian menerapkan penggunaan media gambar pada proses pembelajaran dapat membuat siswa aktif dalam kegiatan pembelajaran, tidak lagi kurang bersemangat, dan tidak mengeluh pada saat proses belajar mengajar di kelas yang dilaksanakan.

\section{SIMPULAN}

Berdasarkan hasil penelitian dan pembahasan, dapat disimpulkan bahwa, hasil penelitian tentang pengaruh penggunaan media gambar terhadap hasil belajar siswa kelas IV SD Negeri Sungguminasa III Kecamatan Somba Opu Kabupaten Gowa ada pengaruh positif penggunaan media gambar terhadap terhadap hasil belajar Bahasa Indonesia siswa kelas IV SD Negeri Sunggumiasa III Kecamatan Somba Opu Kabupaten Gowa.

Pengaruh positif dari penelitian ini dapat dilihat dari berdasarkan hasil analisis persentase kelompok diperoleh data bahwa kehadiran murid $100 \%$ baik pada pertemuan pertama dan kedua. 52,17\% perhatian murid terhadap penjelasan yang diberikan pada pertemuan pertama dan pertemuan kedua $73,91 \%$. 30,43\% yang mengajukan pertanyaan pada pertemuan pertama dan kedua $73,91 \%$. $52,17 \%$ yang melaksanakan setiap intruksi yang diberikan, dan pada pertemuan kedua $82,61 \% .47,83 \%$ yang mengerjakan soal latihan dan pertemuan kedua 93,3\%. 52,17\% yang menjawab pertanyaan pada pertemuan pertama dan pertemuan kedua 95,65\%. $60,87 \%$ yang berpartisipasi aktif selama kegiatan berlangsung dan pada pertemuan kedua $78,26 \%$. 56,52\% yang mengikuti kegiatan secara sukarela pada pertemuan pertama dan pertemuan kedua 73,91\%, selanjutnya $34,78 \%$ yang mampu menilai Copyright (C2018, JRPD, ISSN 2615 - 1723 (Print), ISSN 2615 - 1766 (Online) 
kegiatan yang dilakukan pada pertemuan pertama, pertemuan kedua $73,91 \%$.

Dengan demikian hal ini memberikan indikasi bahwa terjadi peningkatan pada setiap kali pertemuan disebabkan karena setiap siswa serius dan bersungguh-sungguh mengikuti kegiatan, setiap individu melakukan kegiatan dengan baik dan peneliti melaksanakan kegiatan sesuai dengan rencana yang telah ditetapkan sebelumnya.

Berdasarkan hasil analisis statistik deskriptif, diperoleh data bahwa pada hakikatnya terdapat perubahan tingkat hasil belajar, hal ini dapat dilihat dari tingkat hasil belajar siswa dominan berada dalam kategori tinggi sebanyak 16 siswa $(69,57 \%)$, kategori sedang sebanyak 5 siswa $(21,74 \%)$, kategori rendah sebanyak $2(8,7 \%)$ siswa dan tidak ada siswa yang berada pada kategori sangat rendah. Selanjutnya sesuai dengan nilai ratarata skor yang diperoleh sebesar 16.35 dimana nilai rata-rata tersebut berada pada interval 1620 yang berarti tinggi. Hal ini menunjukkan bahwa tingkat hasil belajar siswa kelas IV SD Negeri Sungguminasa III berada pada kategori tinggi. Dengan demikian menerapkan penggunaan media gambar pada proses pembelajaran dapat membuat siswa aktif dalam kegiatan pembelajaran, tidak lagi kurang bersemangat, dan tidak mengeluh pada saat proses belajar mengajar di kelas yang dilaksanakan.

Berdasarkan kesimpulan di atas, maka dikemukakan saran (1) Kepada guru sekolah dasar khususnya pada mata pelajaran Bahasa Indonesia untuk mempertimbangkan Media gambar sebagai alternatif dalam proses pembelajaran pada materi pokok denah dan materi lain yang sesuai. (2) Peneliti selanjutnya yang ingin mengkaji penelitian serupa agar dapat mengembangkan penggunaan media gambar dalam proses belajar mengajar pada permasalahan yang berbeda agar dapat dijadikan sebagai perbandingan.

\section{DAFTAR PUSTAKA}

Ahmad, S. (2013). Teori belajar dan pelajaran di sekolah dasar. Jakarta: kencana.

Ali, M. (1987). Guru Dalam Proses Belajar Mengajar. Bandung: Sinar Baru.
Arfah. (2001). Model-model, media, dan strategi pembelajaran kontekstual (inovatif). Bandung: yrama widya.

Arif. (1984). Media Pengajaran. Jakarta: Depdikbud.

Basuki, W. (1992). Media Pengajaran. Jakarta: Depdikbud.

Depdikbud. (1998). Kurikulum Pendidikan Dasar. Jakarta: Depdikbud.

Fullan, M.G. (2007). The new meaning of educational change (4th ed.). New York, NY: Teachers College Press, Columbia University.

Hudojo, H. (1990). Strategi Belajar Mengajar. Malang: IKIP Malang.

Kustandi, dkk. (2013). Media pembelajaran. Bogor: ghalia indonesia.

Umadi. (2001). Belajar dan Pembelajaran. Jakarta: Rineka Cipta.

Utami. (2000). Media Pendidikan. Jakarta: Rajawali.

Raharjo. (1991). Media pembelajaran. Bandung: yrama widya

Slameto. (2003). Belajar dan Faktor-Faktor yang Mempengaruhinya. Jakarta: Rineka Cipta.

Sulfasyah, Haig, Y., Barratt-Pugh, C. (2015). Indonesian teachers' implementation of new curriculum initiatives in relation to teaching writing in lower primary school. International Journal of Education, $7(4), 53-72$.

Tegeh, I.M. (2008). Media pembelajaran. Bogor: ghalia indonesia. 